\title{
Phenotypic and molecular characterization of corn hybrids released from 1980 to 2000
}

\author{
Caracterização fenotípica e molecular de híbridos de milho lançados entre as décadas de 1980 e 2000
}

\author{
Noryam Bervian Bispo ${ }^{\mathrm{I}}$ Carolina Tessele ${ }^{\mathrm{I}}$ José Fernandes Barbosa Neto $^{\mathrm{II}}$
}

\begin{abstract}
Genetic variability is the basis of plant breeding. In corn, a large and diverse genetic pool permits manipulation of different genotypes, but the genetic diversity of tropical germplasm has been little studied. With the objective of analyzing the amplitude of the genetic variability in 15 hybrids released in different periods by three different seed companies, phenotypic and molecular characterization was carried out in three environments and at two plant densities. The phenotypic assessment showed great similarity among the hybrids, suggesting that the breeding programs have developed genotypes with similar phenotypic traits. The dendogram of the molecular analysis showed clustering according with the different companies suggesting that each corn breeding program make use of different germoplasms. However, although the germplasm was different, it could be inferred that the selection pressure used by the breeders followed the same traits such as plant height, number of rows per ear and kernel weight among others analyzed in the present study, that contributed to the phenotypic uniformity of the genotype.
\end{abstract}

Key words: corn germplasm, genetic diversity, breeding programs.

\section{RESUMO}

O acesso e o uso da variabilidade genética de uma cultura são as bases do melhoramento de plantas. Em milho, um grande e diverso pool gênico permite a manipulação de diferentes genótipos. No entanto, a diversidade genética do germoplasma tropical ainda é pouco estudada. Com o objetivo de analisar a amplitude da variabilidade genética em 15 híbridos lançados em diferentes épocas e provenientes de três diferentes empresas de sementes, foi realizada a caracterização fenotípica e molecular dos genótipos em três ambientes e em duas densidades de semeadura. A avaliação fenotípica revelou uma grande similaridade entre os híbridos, sugerindo que os programas de melhoramento têm desenvolvido genótipos com caracteres fenotípicos semelhantes. A análise molecular, por sua vez, sugere que os programas de melhoramento de milho exploram germoplasma distinto, uma vez que o dendograma mostrou um agrupamento conforme as empresas. Entretanto, apesar de o germoplasma ser distinto, é possível inferir que a pressão de seleção utilizada pelos melhoristas tem seguido a mesma linha, isto é, há uma pressão de seleção por parte das empresas em relação a caracteres, tais como estatura de planta, número de fileiras de grãos e peso de grãos, entre outros analisados no presente trabalho, o que contribuiu para a uniformidade fenotípica dos genótipos.

Palavras-chave: germoplasma de milho, diversidade genética, programas de melhoramento.

\section{INTRODUCTION}

Brazil produces more than 40 million tons of corn a year and hybrids represent about $70 \%$ of the cultivated area (IBGE, 2007). The introduction of hybrid corn in the 1920s stimulated modern agriculture, but advances in crop management has also contributed to higher grain yields (DUVICK, 2001). Recent advances in corn grain yield are the result of increased stress tolerance that is obtained by selection for performance stability in target environments (TOLLENAAR \& LEE, 2002).

The access and use of the genetic diversity of a crop are the basis of genetic improvement (LABORDA et al., 2005). In corn, a large and diverse

I'Universidade Federal do Rio Grande do Sul (UFRGS), Porto Alegre, RS, Brasil.

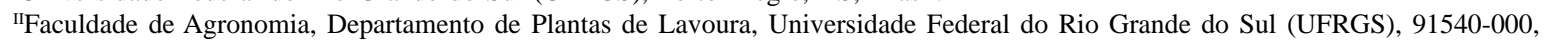
Porto Alegre, RS, Brasil. E-mail: jfbn@ufrgs.br. Autor para correspondência. 
gene pool allows manipulation of different genotypes. Large genetic variability is present in several corn races. Extensive studies on corn have shown the importance and utilization of this large genetic variability for temperate corn germplasm. However, few researches have investigated the genetic diversity of tropical germplasm. LABORDA et al. (2005) assessed 85 Brazilian corn genotypes with molecular markers and detected substantial genetic variability with a high level of polymorphism. There are no precise indications regarding the germplasm exploited by different seed companies of hybrid corn in Brazil. The genetic diversity among breeding programs is little known and the absence of this information has hindered the development of heterotic groups suitable for use in hybrid programs. The breeding programs of the corn seed companies are very dynamic and every year new genotypes are available to the farmers. Each genetic base is adapted to specific environmental conditions, due to the variability present in its constitution (MARTIN et al., 2005). Earliness is a trait that has been sought together with lower plant height and lower ear insertion, because they support higher populations without losses from lodging and broken plants (PEIXOTO et al., 1997).

The objective of this study was to estimate the genetic variability through phenotypic and molecular characterization in corn hybrids released in different periods from different breeding programs.

\section{MATERIAL AND METHODS}

The genetic variability of 15 corn hybrids released from three different seed companies was assessed by phenotypic and molecular analyses in the 2005/2006 and 2006/2007 growing seasons. The hybrids names and characteristics used in this study are described in table 1.

The phenotypic assessment was done at the Estação Experimental Agronômica at the Universidade Federal do Rio Grande do Sul (EEA/ UFRGS), located in Eldorado do Sul/RS, and on the farm belonging to Altair Saccardo, located in Sertão/ RS. The experiments were sowed in Sertão in 2005/ 2006 and 2006/2007, being the first season sown in the late planting (January 2006) and the second season in the regular planting (October 2006). In Eldorado do Sul, the experiment was sowed only in 2006/2007 using the regular planting (October 2006). Furthermore, the hybrids were submitted to two plant densities $(40,000$ and 80,000 plant ha- ${ }^{-1}$ ). The experimental design was a split-plot with four replications. The two plant density treatments were allocated to the main plots and the 15 hybrids to the splitplots in each replication. The splitplots were formed by two $5 \mathrm{~m}$ rows spaced at $0.70 \mathrm{~m}$.

The phenotypic traits assessed were anthesis (AN), silking (SI), plant height (PH), ear height $(\mathrm{EH})$, total number of plants per splitplot (NP), root lodging (RL), stalk lodging (SL), total number of ears per splitplot (NE), number of diseased ears per splitplot

Table 1 - Description of 15 corn hybrids used in the experiment, seed company, hybrid type, cycle and year of release.

\begin{tabular}{|c|c|c|c|c|c|}
\hline Genotype & Hybrid & Seed Company & Hybrid type & Cycle & Year of release \\
\hline 1 & P3232 & Pioneer Sementes & $\mathrm{HT}^{1}$ & $\mathrm{SmP}$ & 1987 \\
\hline 2 & P3063 & Pioneer Sementes & HSM & $\mathrm{P}$ & 1993 \\
\hline 3 & P32R21 & Pioneer Sementes & HS & SpP & 1997 \\
\hline 4 & P30F53 & Pioneer Sementes & HS & $\mathrm{P}$ & 2002 \\
\hline 5 & P30P34 & Pioneer Sementes & HT & $\mathrm{P}$ & 2003 \\
\hline 6 & Master & Syngenta Seeds & HT & $\mathrm{P}$ & Início 90 \\
\hline 7 & Exceler & Syngenta Seeds & HT & $\mathrm{P}$ & Início 90 \\
\hline 8 & Premium & Syngenta Seeds & HS & $\mathrm{P}$ & Final 90 \\
\hline 9 & Penta & Syngenta Seeds & HS & $\mathrm{P}$ & 2003 \\
\hline 10 & Maximus & Syngenta Seeds & HS & $\mathrm{P}$ & 2005 \\
\hline 11 & AS32 & Agroeste & HD & $\mathrm{P}$ & 1995 \\
\hline 12 & AS3466 & Agroeste & HT & $\mathrm{P}$ & 1997 \\
\hline 13 & AS1548 & Agroeste & HS & SpP & 1996 \\
\hline 14 & AS523 & Agroeste & HD & $\mathrm{P}$ & 1999 \\
\hline 15 & AS1565 & Agroeste & HS & $\mathrm{P}$ & 2004 \\
\hline
\end{tabular}

${ }^{1}$ - Abbreviation: HS = Single Hybrid; HSM = Modified Single Hybrid; HT = Triple Hybrid; HD = Double Hybrid; $\mathrm{P}=$ Early; SmP = Semi early; SpP = Super Early. 
(ND), grain yield (GY), ear length (EL), cob diameter (CD), number of rows per ear (NR), kernel weight (weight of 1000 grains) (KW) and kernel depth (KD). Flowering was measured using the formula $D D=\sum(T-10)$, where $\mathrm{DD}=$ degrees day and $\mathrm{T}=$ mean daily temperature. The data was submitted to an analysis of variance and the means were compared by Tukey test $5 \%$. In addition, the phenotypic traits were used to estimate the Euclidean distances among the hybrids. For this calculation, the values of the variables were standardized by the mean and standard deviation. From these results, the hybrids were clustered using the UPGMA (Unweighted Pair Grouped Method Average) method.

The molecular assessment was carried out in the Laboratório de Biotecnologia Vegetal, located in the Departamento de Plantas de Lavoura of the Faculdade de Agronomia/UFRGS. The protocol used to extract the DNA was MURRAY \& THOMPSON (1980). The SSR molecular marker technique was used and thirty-four primers distributed on all the corn chromosomes were tested. The sampling consisted of collecting leaves from ten plants per genotype. The SSR reactions were prepared for a $20 \mathrm{ml}$ volume. Each reaction contained $10.2 \mu \mathrm{l}$ sterilized water, $2 \mu \mathrm{l}$ Buffer 10X (Invitrogen), 0.6 $\mu \mathrm{l} \mathrm{MgCl}_{2}$ (Invitrogen), 0.4 $\mu \mathrm{ldNTP}$ mix (Invitrogen), 0.3 $\mu \mathrm{l} \mathrm{F} \mathrm{primer} \mathrm{(forward),} \mathrm{0.3 \mu l} \mathrm{R} \mathrm{primer}$ (reverse), $0.2 \mu \mathrm{l}$ Taq-DNA Polimerase enzyme (Invitrogen, $5 \mathrm{u} \mu \mathrm{l}^{-1}$ ), and $6 \mu \mathrm{l}$ of DNA. The DNA was amplified using a touchdown type program in a thermocycler. The 100pb DNA Ladder marker (Invitrogen) was used as molecular weight standard. PCR reactions and gel visualization were carried out for all individuals together for each primer. The amplified DNA fragments were separated in polyacrylamide gel $5 \%$ and visualized by staining with silver nitrate.

The number of alleles per locus was observed and the polymorphism contents (PIC), was estimated using the formula PIC $=1-\sum p u^{2}$, where $p u=$ frequency of the allele $u$. The genetic similarity of the hybrid was estimated by the ROGERS (1972) coefficient and the dendrogram was obtained by the UPGMA method.

\section{RESULTS AND DISCUSSION}

In the present study, the environment was important in the expression of most of the variables analyzed. The Sertão environment, in the 2006/07 growing season, presented the higher grain yield $\left(10,986 \mathrm{~kg} \mathrm{ha}^{-1}\right)$ compared to the other two environments assessed. This was certainly due to the fact that the planting occurred in a preferential period and in a location that presented favorable conditions for corn development, such as good altitude (around 730m), favorable rainfall index, and a soil type (latossol) suitable for the crop development. Sowing was late in the second environment assessed (Sertão 2005/06), which reduced the grain yield average $\left(7,348 \mathrm{~kg} \mathrm{ha}^{-1}\right)$, although the location was favorable. In the Eldorado do Sul environment sowing was carried out in the regular planting, but plant growing condition and insufficient rainfall during the crop development limited grain yield of the hybrids $\left(5,786 \mathrm{~kg} \mathrm{ha}^{-1}\right)$. Overall, the environment of Sertão 2006/07 presented a performance with shorter plants, earlier cycle, larger ear length and higher kernel weight than the other environments. FORSTHOFER et al. (2006) detected differences regarding late and early sowing and concluded that late sowing determined the formation of lighter grains in the systems with high management investments, compared to the other sowing periods. This was attributed to the fact that in late sowing most of the grain filling period would occur in months with lower temperature and incident sun radiation that would limit the photosynthesis activity and carbohydrate translocation of the vegetative fractions of the plant to the grains.

Plant density represents the agronomic factor that has changed most during the last six decades (TOLLENAAR \& LEE, 2002). This variable affected the total number of ears, that is a direct consequence of the total number per area. Plant density also affected other traits. The increase in the population from 40,000 to 80,000 plant ha $^{-1}$ determined shorter ear lengths and smaller kernel depth and weight. However, the grain yield was not statistically different in this study probably due to compensation of the yield components and to the larger disease index at the 80,000 plant ha ${ }^{-1}$ density. According to ALMEIDA et al. (2000), earlier genotype presents fewer opened leaves at anthesis, small leaf area and reduced final plant height. These characteristics make intra-specific competition for environmental resources and are potentially smaller in the short cycle hybrid. Therefore, the maximization of grain yield of these genotypes requires greater number of individuals per area.

The results indicated that the 15 hybrids assessed were significantly different for eight traits analyzed: ear height, total number of ears, ear length, cob diameter, number of rows per ear, kernel depth, kernel weight, and grain yield. The other variables (plant height, anthesis, silking, and number of diseased ears) were not significantly different compared to the hybrids analyzed. Root lodging and stalk lodging had very low rates of incidence ( 0.1 and 0.3 plants per plot, 
respectively) across all hybrids tested. This low rate suggests that these hybrids, selected for short plant height, are more resistant to root lodging and stalk lodging.

Plant height and ear height ranged from $2.26 \mathrm{~m}$ to $2.08 \mathrm{~m}$ and $125 \mathrm{~cm}$ to $109 \mathrm{~cm}$, respectively (Table 2). The variation in the cycle was from 876 to 869 degrees day for anthesis and 842 to 872 degrees day for silking (Table 2). These are adaptive traits, closely linked to the environment with simple inheritance (LOCATELLI et al., 2002). The breeding programs analyzed had probably already adjusted these traits in the last 20 years, because they are relatively easy to select. The percentage of diseased ears was high, ranging on average from 22.2\% (AS1548) to 35.3\% (P30F53) (Table 2). The high diseased ears level may have occurred due to the high rainfall in the first year of study. The hybrids analyzed showed statistical differences for the traits ear length and number of rows per ear. However, the variation in ear length was reduced, ranging only $1.9 \mathrm{~cm}(15.5$ to $17.4 \mathrm{~cm})$. The mean number of rows per ear of the hybrids ranged from 13.9 to 17.9 , and there was a relationship with the year in which the hybrid was released. Generally, older hybrids showed a smaller number of rows per ear which suggests an increase in the number of rows per ear in the new hybrids to the corn seed industry.

Most of the hybrids studied belong to the early development cycle, except for the P32R21 and AS1548 hybrids that are super early and the P3232 hybrid that is semi early. The earliness characteristic has been sought together with shorter plants and low ear insertion, because these plants can withstand better high plant populations without damage from root and stalk lodging (PEIXOTO et al., 1997). The smaller demand in heat units for flowering of the contemporary hybrids of Southern Brazil favors the production of plants with low ear insertion height (SANGOI et al., 2002). With this, the center of gravity of the plant is better balanced and its sustainability is increased.

Grain yield is the most important selection criterion used by commercial corn breeders (DUVICK \& CASSMAN, 1999). The mean grain yield obtained in this experiment can be considered high $\left(8,040 \mathrm{~kg} \mathrm{ha}^{-1}\right)$ when compared to the average grain yield presented by Brazil in 2006/07, 3,637 $\mathrm{kg} \mathrm{ha}^{-1}$. The average grain yield in state of Rio Grande do Sul, in the 2006/07 growing season was $1,385 \mathrm{~kg} \mathrm{ha}^{-1}$ (CONAB, 2007). SANGOI et al. (2003) obtained mean grain yields that ranged from 3,000 to $15,000 \mathrm{~kg} \mathrm{ha}^{-1}$ in Eldorado do Sul, while SILVA et al. (1999) reported the mean grain yields in Eldorado do Sul of around 7,400 $\mathrm{kg} \mathrm{ha}^{-1}$.

There was no genotype $\mathrm{x}$ density or triple interaction (density $\mathrm{x}$ environment $\mathrm{x}$ hybrid). But the genotype $x$ environment interaction was significant for the following traits: cob diameter, total number of ears, depth and weight kernel, and grain yield. In favorable environments, the hybrid expresses its full potential yields, however when the environment is not favorable, the hybrids were more uniforms. The environment Sertão 2006/07 showed the best grain yield performance for the hybrids Master, Exceler, Premium, Penta, Maximus, AS32 and AS3466 (Table 3). The hybrid Penta had the best yields in the three environments tested.

Table 2 - Means for plant height (PH), ear height (EH), anthesis, (AN), silking (SI), number of diseased ears (ND), ear length (EL), and number of rows per ear (NR) of 15 corn hybrids cultivated in three different environments.

\begin{tabular}{|c|c|c|c|c|c|c|c|c|}
\hline Hybrid & PH (m) & $\mathrm{EH}$ & $\mathrm{cm})$ & AN (DD) & SI (DD) & ND & EL (cm) & NR \\
\hline P3232 & 2.23 & 122 & bc & 869 & 872 & 8.8 & $16.7 \mathrm{ab}$ & $13.9 \mathrm{~h}$ \\
\hline P3063 & 2.18 & 112 & $a b$ & 839 & 842 & 11.0 & 16.6 bc & 15.3 efg \\
\hline P32R21 & 2.23 & 114 & abc & 836 & 844 & 9.3 & 17.4 & 17.0 bc \\
\hline P30F53 & 2.14 & 112 & $a b$ & 855 & 862 & 11.8 & 16.4 bc & $16.2 \mathrm{~cd}$ \\
\hline P30P34 & 2.23 & 125 & C & 838 & 844 & 10.1 & 16.4 bcd & 15.6 def \\
\hline Master & 2.24 & 124 & c & 846 & 855 & 8.8 & 15.9 cde & 14.9 fg \\
\hline Exceler & 2.16 & 121 & bc & 852 & 856 & 7.1 & 15.6 & $15.8 \mathrm{de}$ \\
\hline Premium & 2.24 & 122 & bc & 850 & 862 & 9.3 & 15.7 & 15.2 efg \\
\hline Penta & 2.08 & 119 & bc & 840 & 844 & 9.5 & 16.1 & 15.6 def \\
\hline Maximus & 2.24 & 125 & c & 852 & 854 & 8.7 & 16.1 & 17.9 а \\
\hline AS32 & 2.26 & 124 & c & 843 & 849 & 9.2 & 16.2 & $14.8 \mathrm{fg}$ \\
\hline AS3466 & 2.17 & 117 & abc & 864 & 863 & 10.9 & 16.5 & $14.7 \mathrm{gh}$ \\
\hline AS1548 & 2.10 & 109 & $\mathrm{a}$ & 843 & 848 & 7.5 & 15.9 & $17.2 \mathrm{ab}$ \\
\hline AS523 & 2.13 & 113 & $\mathrm{ab}$ & 851 & 858 & 7.3 & 15.5 & 16.7 \\
\hline AS1565 & 2.19 & 117 & abc & 842 & 844 & 8.9 & 16.4 bcd & $16.3 \mathrm{~cd}$ \\
\hline
\end{tabular}

*Means followed by the same letter in the column do not differ significantly by T test $(\alpha=0,05)$.

Ciência Rural, v.39, n.7, out, 2009. 
Table 3 - Means for number of ears (NE), kernel depth (KD), kernel weight (KW), cob diameter (CD), and grain yield (GY) of 15 corn hybrids evaluated in Eldorado do Sul/2006 (E06), Sertão/2005 (S05), and Sertão/2006 (S06).

\begin{tabular}{|c|c|c|c|c|c|c|c|c|c|c|c|c|c|c|c|}
\hline \multirow[b]{2}{*}{ Hybrid } & \multicolumn{3}{|c|}{-----------NE----------- } & \multicolumn{3}{|c|}{-----------KD----------- } & \multicolumn{3}{|c|}{-----------KW----------- } & \multicolumn{3}{|c|}{-----------CD----------- } & \multicolumn{3}{|c|}{----------GY--------- } \\
\hline & E06 & S05 & S06 & E06 & S05 & S06 & E06 & S05 & S06 & E06 & S05 & S06 & E06 & S05 & S06 \\
\hline P3232 & 28.1 & 26.8 & 38.5 & 1.75 & 1.90 & 1.89 & 0.41 & 0.46 & 0.42 & 2.73 & 3.03 & 2.76 & 5859 & 6250 & 10071 \\
\hline P3063 & 33.6 & 29.1 & 42.0 & 1.97 & 1.90 & 1.98 & 0.38 & 0.40 & 0.38 & 2.62 & 2.92 & 2.72 & 7432 & 6857 & 10392 \\
\hline P32R21 & 28.6 & 26.1 & 42.6 & 1.88 & 1.86 & 1.88 & 0.33 & 0.39 & 0.38 & 2.71 & 3.01 & 2.68 & 5475 & 6107 & 10303 \\
\hline P30F53 & 28.0 & 29.5 & 42.9 & 2.05 & 1.99 & 1.97 & 0.40 & 0.41 & 0.39 & 2.67 & 2.95 & 2.90 & 6244 & 6892 & 11750 \\
\hline Р30Р34 & 29.2 & 27.2 & 41.4 & 1.88 & 1.87 & 1.83 & 0.38 & 0.40 & 0.41 & 2.72 & 3.00 & 2.92 & 5963 & 6678 & 11732 \\
\hline Master & 27.6 & 37.0 & 44.5 & 1.92 & 2.02 & 1.71 & 0.36 & 0.40 & 0.41 & 2.44 & 2.79 & 2.78 & 4050 & 8982 & 10642 \\
\hline Exceler & 18.2 & 34.6 & 41.7 & 1.90 & 2.04 & 1.80 & 0.35 & 0.41 & 0.37 & 2.68 & 3.01 & 2.75 & 3591 & 8910 & 9678 \\
\hline Premium & 32.0 & 33.2 & 43.1 & 2.04 & 2.14 & 1.91 & 0.35 & 0.41 & 0.41 & 2.65 & 2.92 & 2.73 & 5653 & 8571 & 12178 \\
\hline Penta & 36.7 & 29.8 & 43.4 & 1.90 & 2.02 & 1.82 & 0.37 & 0.40 & 0.39 & 2.72 & 3.00 & 2.97 & 7700 & 8500 & 11625 \\
\hline Maximus & 24.7 & 30.0 & 42.0 & 1.86 & 2.13 & 1.74 & 0.36 & 0.39 & 0.41 & 2.94 & 2.92 & 3.01 & 4641 & 7589 & 11821 \\
\hline AS32 & 29.1 & 31.3 & 45.1 & 1.73 & 1.87 & 1.82 & 0.31 & 0.34 & 0.41 & 2.60 & 2.87 & 2.80 & 5355 & 7535 & 11535 \\
\hline AS3466 & 32.0 & 28.5 & 44.4 & 1.66 & 1.82 & 1.80 & 0.34 & 0.37 & 0.39 & 2.70 & 3.06 & 2.84 & 5137 & 7267 & 10482 \\
\hline AS1548 & 33.1 & 27.1 & 41.1 & 1.61 & 1.94 & 1.93 & 0.35 & 0.34 & 0.37 & 3.02 & 3.11 & 2.89 & 6875 & 7000 & 9892 \\
\hline AS523 & 23.6 & 26.1 & 39.7 & 1.80 & 1.98 & 2.03 & 0.32 & 0.34 & 0.36 & 2.77 & 2.79 & 2.71 & 4644 & 6553 & 11678 \\
\hline AS1565 & 32.7 & 27.0 & 42.6 & 1.77 & 1.87 & 1.78 & 0.35 & 0.35 & 0.38 & 2.74 & 2.79 & 2.74 & 8172 & 6535 & 11017 \\
\hline DMS (5\%) & 7.2 & 7.2 & 7.2 & 0.19 & 0.19 & 0.19 & 0.04 & 0.04 & 0.04 & 0.17 & 0.17 & 0.17 & 1751 & 1751 & 1751 \\
\hline
\end{tabular}

The others hybrids have shown superior performance depending on the environment, except for the hybrids P3232 and P32R21 that presented lower yields in the three environments evaluated. The environment Sertão 2006/07 presented hybrids with large number of ears and kernel weight (Table 3).

In general, the environment Eldorado do Sul was not suitable to differentiate hybrids since the performances were poor for all traits. RIBEIRO et al. (2000) also detected interactions when they analyzed adaptability and stability indexes of different corn genotypes in 36 environments in Minas Gerais state. GONÇALVES et al. (1999) also detected cultivar x location and cultivar $\mathrm{x}$ year interactions in corn genotypes in the states of São Paulo, Goias and Paraná. On the other hand, there was no significant interaction between hybrid and density in the present study. This response was probably due to the fact that the tested hybrids did not present significant variation for plant height and cycle that are fundamental factors in the response to the increase in plant number by area (PEIXOTO et al., 1997; ALMEIDA et al., 2000).

A distance index was estimated using the phenotypic traits assessed. The Euclidean distance takes into consideration a multi-dimensional space and places each hybrid within this space, so that the degree of divergence amongst them can be estimated. The results indicated a great similarity among the hybrids, suggesting that the breeding programs have developed genotypes with similar phenotypic traits (Figure 1A). Similarly, this similarity may also be attributed to the fact that a small number of years were analyzed which included a breeding stage where the main adaptive traits were already uniform. The mean distance among the hybrids was 0.04 , ranging from 0.001 to 0.132 .

In the molecular analysis, the SSR primers analyzed detected 145 alleles in the 34 loci analyzed, with an average of 4.26 alleles per locus. Only one locus was monomorphic and the others were polymorphic, ranging from two to eight alleles per locus. The allele size varied from 70 to $250 \mathrm{bp}$. The PIC values that give an estimate of the discriminating power of the marker presented an average value of 0.71 , ranging from 0.29 to 0.95 (umc1702 and umc1018 primers, respectively). The dendogram constructed from the molecular marker formed four groups (Figure 1B). The hybrids from Pioneer Company grouped together, forming the first group. The second group was formed by four hybrids from Syngenta Company. The other group was formed by three hybrids from Agroeste Company, and the last group was formed by the hybrid Premium from Syngenta Company and the hybrids AS1548 and AS1565 from Agroeste Company. The ROGERS (1972) similarity mean among all the hybrids was 0,78 , suggesting that companies are using diverse germplasm in their breeding programs. SENIOR et al. (1998) observed a variation of genetic similarity between 0.21 and 0.90 among corn lines, showing the diversity of the crop.

The molecular analysis results suggested that the companies are using different germplasm in their breeding programs, because grouping in the

Ciência Rural, v.39, n.7, out, 2009. 


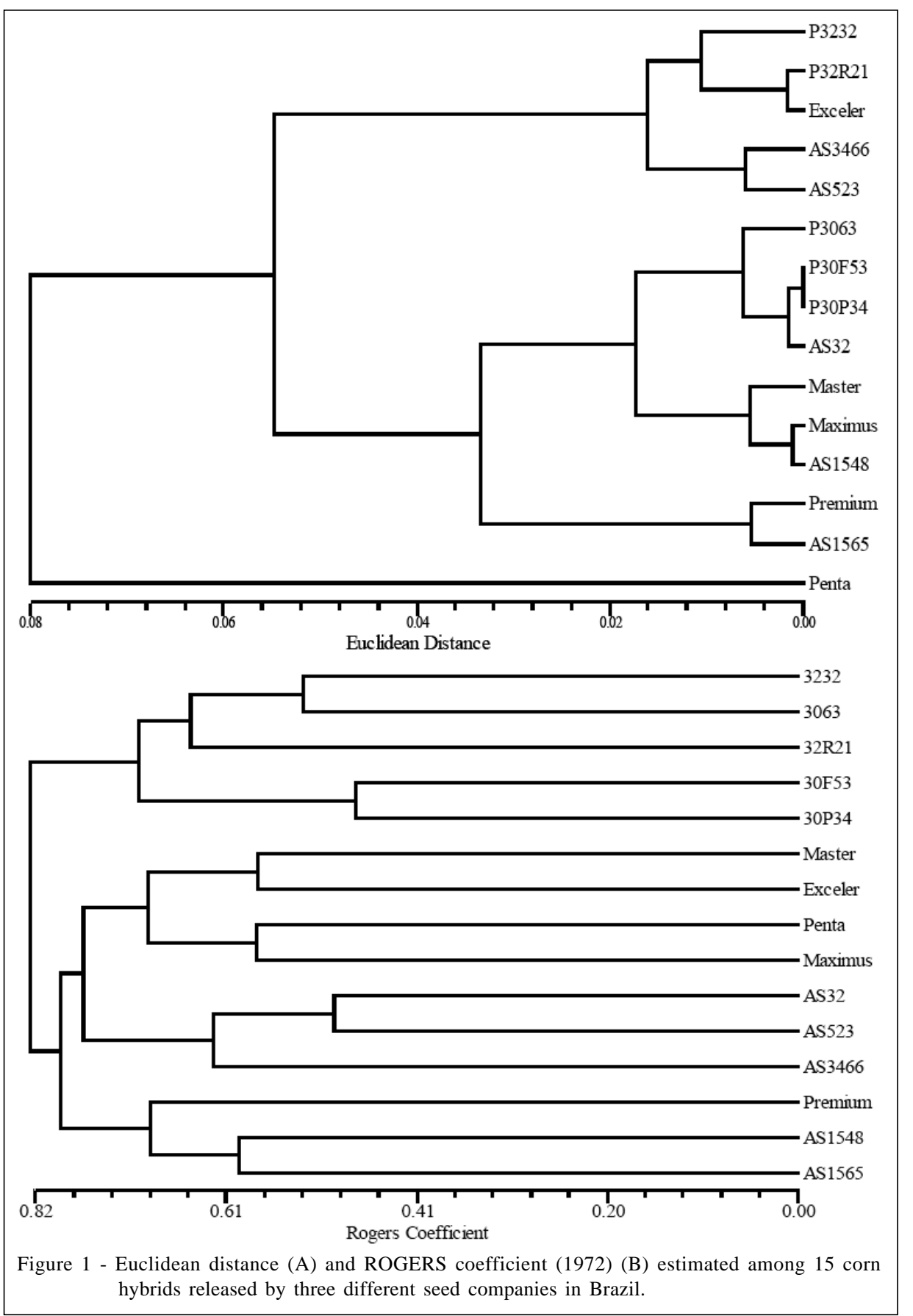

dendogram was according to the companies. The phenotypic traits analysis indicated that the selection pressure used by the breeders followed the same line, focus mainly in plant height, number of rows per ear, and grain weight among others analyzed in the present study These traits contributed to the phenotypic uniformity of the genotypes. If other traits had been assessed, such as disease resistance, there would be relevant differences that would confirm the diverse origin of the germplasm used by the different companies.

\section{ACKNOWLEDGEMENTS}

The authors acknowledge Conselho Nacional de Desenvolvimento Científico e Tecnológico (CNPQ) and Coordenação de Aperfeiçoamento de Pessoal de Nível Superior

Ciência Rural, v.39, n.7, out, 2009. 
(CAPES) for financial support and to Pioneer, Syngenta, and Agroeste Companies for the seeds of their hybrids.

\section{REFERENCES}

ALMEIDA, M.L. et al. Incremento na densidade de plantas: uma alternativa para aumentar o rendimento de grãos de milho em regiões de curta estação estival de crescimento. Ciência Rural, v.30, p.23-29, 2000. Disponível em: <http:// www.scielo.br/scielo.php?script=sci_arttext\&pid=S010384782000000100004\&lng=pt\&nrm=iso $>$. Acesso em: 07 mai. 2009. doi: 10.1590/S0103-84782000000100004.

CONAB - Companhia Nacional de Abastecimento. Central de informações agropecuárias. Acessado em: 02 jul. 2007. Online. Disponível em: <http://www.conab.gov.br/conabweb/ download/safra/MilhoTotalSerieHist.xls>.

DUVICK, D.N.; CASSMAN, K.G. Post-green revolution trends in yield potential of temperate maize in the North-Central United States. Crop Science, v.39, p.1622-1630, 1999.

DUVICK, D.N. Biotechnology in the 1930s: the development of hybrid maize. Nature Reviews Genetics, v.2, p.69-74, 2001. Disponível em: <http://www.nature.com/nrg/journal/v2/ n1/abs/nrg0101_069a.html>. Acesso em: 07 mai. 2009. doi: $10.1038 / 35047587$

FORSTHOFER, E.L. et al. Desempenho agronômico e econômico do milho em diferentes níveis de manejo e épocas de semeadura. Pesquisa Agropecuária Brasileira, v.41, p.399-407, 2006. Disponível em: <http://www.scielo.br/ s c i e lo.ph p ? s c ript = sci_art text \& pid = S $0100-$ 204X2006000300005\&lng=en\&nrm=iso $>$. Acesso em: 07 mai. 2009. doi: 10.1590/S0100-204X2006000300005.

GONÇALVES, F.M.A. et al. Importância das interações cultivares $\mathrm{x}$ locais e cultivares $\mathrm{x}$ anos na avaliação de milho na safrinha. Pesquisa Agropecuária Brasileira, v.34, p.1175-1181, 1999. Disponível em: <http://www.scielo.br/ s c i e lo.ph p ? s c ript = sci_art text \& pid = S $0100-$ 204X1999000700009\&lng=en\&nrm=iso $>$. Acesso em: 07 mai. 2009.

IBGE. Sistema IBGE de recuperação automática. Brasília, 2005. Acessado em 12 mar. 2007. Online. Disponível em $<$ http://www.sidra.ibge.gov.br>.

LABORDA, P.R. et al. Tropical maize germplasm: what can we say about its genetic diversity in the light of molecular markers? Theoretical and Applied Genetics, v.111, p.12881299, 2005. Disponível em: <http://www.springerlink.com/ content/q057008902368n70/>. Acesso em: 07 mai. 2009. doi: 10.1007/s00122-005-0055-7.

LOCATELLI, A.B. et al. Capacidade combinatória de nove linhagens endogâmicas de milho (Zea mays L.) em dois ambientes. Ciência Rural, v.32, p.365-370, 2002. Disponível em: <http:/ /www.scielo.br/scielo.php?script=sci_arttext\&pid=S010384782002000300001\&lng=pt\&nrm=iso $>$. Acesso em: 07 mai. 2009. doi: 10.1590/S0103-84782002000300001.

MARTIN, T.N. et al. Bases genéticas de milho e alterações no plano experimental. Pesquisa Agropecuária Brasileira, v.40, p.35-40, 2005. Disponível em: <http://www.scielo.br/ s ci el o.ph p ? s c ri pt = s ci_art t ext \& pi d = S 0100 204X2005000100005\&lng $=$ en $\& n r m=i s o>$. Acesso em: 07 mai. 2009. doi: 10.1590/S0100-204X2005000100005.

MURRAY, M.; THOMPSON, W.F. Rapid isolation of highmolecular-weight plant DNA. Nucleic Acids Research, v.8, p.4321-4325, 1980.

PEIXOTO, C.M. et al. Produtividade de híbridos de milho em função da densidade de plantas, em dois níveis de manejo da água e da adubação. Pesquisa Agropecuária Gaúcha, v.3, p.63-71, 1997.

RIBEIRO, P.H.E. et al. Adaptabilidade e estabilidade de genótipos de milho em diferentes condições ambientais. Pesquisa Agropecuária Brasileira, v.35, p.2213-2222, 2000. Disponível em: <http://www.scielo.br/scielo.php?script=sci_arttext\&pid=S0100204X2000001100013\&lng=en\&nrm=iso >. Acesso em: 07 mai. 2009. doi: 10.1590/S0100-204X2000001100013.

ROGERS, J.S. Measures of genetic similarity and genetic distance. Studies in Genetic. VII. University Texas Publication, v.7213, p.145-153, 1972.

SANGOI, L. et al. Bases morfofisiológicas para maior tolerância dos híbridos modernos de milho a altas densidades de plantas. Bragantia, v.61, p.101-110, 2002. Disponível em: <http:// www.scielo.br/scielo.php?script=sci_arttext\&pid=S000687052002000200003\&lng=en\&nrm=iso $>$. Acesso em: 07 mai. 2009. doi: 10.1590/S0006-87052002000200003.

SANGOI, L. et al. Níveis de manejo na cultura do milho em dois ambientes contrastantes: análise técnico-econômica. Ciência Rural, v.33, p.1021-1029, 2003. Disponível em: <http:// www.scielo.br/scielo.php?script=sci_arttext\&pid=S010384782003000600005\&lng=pt\&nrm=iso >. Acesso em: 07 mai. 2009. doi: 10.1590/S0103-84782003000600005.

SENIOR, M.L. et al. Utility of SSR for determining genetic similarities and relationships in maize using an agarose gel system. Crop Science, v.38, p.1088-1098, 1998. Disponível em: <http://crop.scijournals.org/cgi/content/abstract/38/4/ 1088>. Acesso em: 07 mai. 2009.

SILVA, P.R.F. et al. Resposta de híbridos de milho irrigado à densidade de plantas em três épocas de semeadura. Pesquisa Agropecuária Brasileira, v.34,p.585-592, 1999. Disponível em: <http:// www.scielo.br/scielo.php?script=sci_arttext \&pid=S0100204X1999000400009\&lng=en\&nrm=iso>. Acesso em: 07 mai. 2009. doi: 10.1590/S0100-204X1999000400009.

TOLLENAAR, M.; LEE, E.A. Yield potential, yield stability and stress tolerance in maize. Field Crops Research, v.75, p.161-169, 2002. Disponível em: <http://www.sciencedirect.com/ science?_ob=ArticleURL\&_udi=B6T6M-45D16CG $3 \&$ _ u s e r $=687304 \&$ _ c over Dat e $=05 / 10 /$ $2002 \&$ alid $=914409140 \&$ \&_doc $=1 \&$ \&mt $=$ high\&_orig $=$ search\&_ c di $=5034 \&$ \& sort $=$ d \&_d o c a n chor $=\&$ vi e w $=$ c \& c t $=1 \&$ \&_a c c t $=$ C $000037798 \&$ \& version $=18$ _ u r l Versio n $=0$ \&_u se ri d $=687304 \&$ m d $\overline{5}=$ bd7a7df55c560ac3e0604184ce124b6c >. Acesso em: 07 mai. 2009. doi: 10.1016/S0378-4290(02)00024-2. 